UDK 338.22:656.078

JEL H54, L10, L33, M11, O31, O32

DOI 10.31375/2226-1915-2020-3-61-76

Olga Afanasieva

Ph.D., associate Professor of the Department «Management and Marketing»

olga-af@ukr.net

ORCID: 0000-0002-5114-4798

Yana Pokora

Bachelor's degree in Management pokora.yana24@gmail.com

Odessa National Maritime University, Odesa, Ukraine

\title{
THE FORMATION OF INNOVATION POLICY OF THE SEAPORT
}

Abstract. Nowadays the economic development of countries is determined not by natural resources and industrial production, but by the aggregate ability of economic entities to implement new ideas to meet consumer demand for certain goods or services. Seaports are key points of foreign trade. The quality and volume of exports of transport services, the level of competitiveness of national goods on the world market depend on the efficiency of seaports. There is a question of the necessity to develop an innovation policy that will stimulate economic activity, increase competitiveness, encourage the implementation of innovations, and resolve emerging contradictions.

In this article, the concept of "innovation policy" as a systematic approach to innovation in the enterprise was described. The main components of the enterprise innovation policy are considered in general and the seaport in particular. The main purpose of this work is to study the theoretical aspects of the innovation policy of the seaport, highlight the main stages of its formation and determine the method of attracting investment as an integral part of innovation development.

The following stages of the formation of the innovation policy were defined: revealing the relevance of the formation of the innovation policy for the enterprise; evaluation of innovation potential (proposed system of indicators); the formation of strategy of innovative development of the enterprise (the concept of innovation strategy and its types are considered); development of the program of innovative activity; the creation of a system of evaluation of the innovation program (as the main way of efficiency of introduction of innovations in the enterprise.

The classification of innovation strategies and a system of indicators for a comprehensive assessment of the innovation potential of the enterprise are highlighted. The types of effect from the implementation of innovation policy are determined. We identified the relevance of the formation of innovation policy for seaports of Ukraine, ways to determine their innovation potential, as well as proposed a way to attract investment as an integral part of innovation. The most effective is the introduction of concessions (forms of public-private partnership - PPP), which will stimulate the development of innovation in ports. For the state, the concession is always an instrument of economic growth and increases the level of market competition, attracting management resources, the latest equipment, technology, and modern organization of production processes while reducing budget costs. The investor is also interested in the concession like in the possibility of risk sharing, guarantees of protection of the concessionaire's rights, the imposition on the state of obligations to facilitate the implementation of projects.

The result of the implementation of innovation policy depends on taking into account the peculiarities of the state of the maritime trade enterprise. The analysis of the study showed that the application of innovations in domestic seaports is necessary and should be accompanied by attracting a significant amount of investment.

Keywords: innovation, innovation policy, seaport, innovation activity, indicators of the effectiveness, innovation potential.

(C) Afanasieva Olga., Pokora Yana., 2020 
DEVELOPMENT OF MANAGEMENT AND ENTREPRENEURSHIP METHODS ON TRANSPORT, № 3 (72), 2020
РОЗВИТОК МЕТОДІВ

УПРАВЛІННЯ ТА ГОСПОДАРЮВАННЯ

НА ТРАНСПОРТІ, № 3 (72), 2020
УДК 338.22:656.078

JEL H54, L10, L33, M11, O31, O32

DOI 10.31375/2226-1915-2020-3-61-76

О.К. Афанасьєва

к.е.н., доцент кафедри

«Менеджмент і маркетинг»

olga-af@ukr.net

ORCID: 0000-0002-5114-4798

Я.Ю. Покора

бакалавр, спеціальність «Менеджмент» pokora.yana24@gmail.com

Одеський національний морський університет, Одеса, Украӥна

\section{ФОРМУВАННЯ ІННОВАЦЙНОӦ ПОЛІТИКИ МОРСЬКОГО ПОРТУ}

Анотація. У даній статті розглянуто поняття «інновачійна політика», як системний підхід до впровадження інновачій на підприємстві. Розглянуті головні складові інновачійної політики підприємства загалом та морського порту зокрема. Сформовано загальний порядок ї̈ формування. Саме дотримання порядку формування інноваційної політики підприємства забезпечує ефективну інновачійну діяльність

Було визначено наступні етапи формування інновачійної політики: виявлення актуальності формування інновачійної політики для підприсмства; оцінка інноваційного потениіалу (запропоновано систему показників); формування стратегї та головні ї̈ види; розроблення програми інновачійної діяльності; створення системи оцінки інноваційної програми (як головний спосіб визначення результативності впровадження інновацій на підприємстві).

Виділено класифікаціюю інноваційних стратегій та запропоновано систему показників для комплексної очінки інновачійного потенціалу підприємства. Визначені види ефекту від реалізації інноваційної політики. Було зазначено актуальність формування інноваційної політики для морських портів України, способи визначення їх інноваційного потенціалу, а також запропоновано спосіб залучення інвестииій, як невід'ємної частини інноваиійної діяльності.

Ключові слова: інновачї, інновачійна політика, показники ефективності, морський порт, інновачійна діяльність, інновачійний потенціал.
УДК 338.22:656.078

JEL H54, L10, L33, M11, O31, 032

DOI 10.31375/2226-1915-2020-3-61-76

О.К. Афанасьева

к.э.н., доцент кафедры

«Менеджмент и маркетинг»

olga-af@ukr.net

ORCID: 0000-0002-5114-4798

Я.Ю. Покора

бакалавр, специальность «Менеджмент» pokora.yana24@gmail.com

Одесский национальный морской университет, Одесса, Украина

\section{ФОРМИРОВАНИЕ \\ ИННОВАЦИОННОЙ ПОЛИТИКИ МОРСКОГО ПОРТА}

Аннотация. В данной статье рассмотрено понятие «инновационная политика», как системный подход к внедрению инновачий на предприятии. Рассмотрены основные составляющие инновационной политики предприятия в целом и морского порта в частности. Сформирован общий порядок ее формирования. Именно соблюдение порядка формирования инновационной политики предприятия обеспечивает эффективную инноваиионную деятельность.

Были определень следуюшие этапь формирования инновачионной политики: выявление актуальности формирования инновационной политики для предприятия; оценка инновационного потенциала (предложена система показателей); формирование стратегии и главные ее виды; разработка программы инновационной деятельности; создание системы оценки инновационной программы (как главный способ определения результативности внедрения инноваций на предприятии).

Выделена классификаџия инновационных стратегий и предложена система показателей для комплексной оценки инновационного потенцииала предприятия. Определены виды эффекта от реализации инновационной политики. Была отмечена актуальность формирования инновачионной политики для морских портов Украины, способы определения их инновационного потенцииала, а также предложен способ привлечения инвестиций, как неотъемлемой части инновационной деятельности.

Ключевые слова: инновачии, инновациионная политика, показатели эффективности, морской порт, инновационная деятельность, инновационный потенцииал. 
DEVELOPMENT OF MANAGEMENT

AND ENTREPRENEURSHIP METHODS ON TRANSPORT, № 3 (72), 2020
РОЗВИТОК МЕТОДІВ

УПРАВЛІННЯ ТА ГОСПОДАРЮВАННЯ

НА ТРАНСПОРТІ, № 3 (72), 2020
Problem statement. Nowadays, the economic development of countries is determined not by natural resources and industrial production volumes, but by the aggregate ability of economic entities to implement new ideas to meet consumer demand for certain goods or services. Seaports are key points of foreign trade. The conditions for the entry of the national economy into the global and European regional economic systems cause complete changes in the field of maritime transport and in the system of seaports of Ukraine. The quality and volume of exports of transport services, the level of competitiveness of national goods on the world market depend on the efficiency of seaports. The question arises of the need to develop an innovation policy that will stimulate economic activity, increase competitiveness, encourage innovation, and resolve emer-ging contradictions.

Review of the last research and publications. Among the scientists who studied innovation policy, we can mention S. Ilyashenko [1], R. Kvasnytska, and S. Ardashkina [2], M. Rymar and N. Lykun [3], T. Maksymov [4], O. Chernenko [5] and others. The prob-lems of innovative development of sea-ports are devoted to the works of O. Alyabieva [6], M. Maltsev [7], M. Postan [8], N. Roshchina [9] and others, but their researches don't take into account the full process of creating innovation policy for seaports.

Problems of seaports are multifactor, ambiguous, and require a systematic approach, especially in times of crisis, as they determine both the interests of the state and the interests of strategic investors in port capacity. The process of privatization of property, the formation of new economic relations on its basis will allow the demonopolization of the industry's economy and create a competitive environment among port operators. The issue of attracting investment in the context of innovation, with some exceptions, was insufficiently considered. As ports play an important role in foreign trade and production of the state, the formation of innovation policy of the port has not been considered, this is what the study will be devoted to.

The aim of the research. The main purpose of this work is to study the theoretical aspects of the innovation policy of the seaport, highlight the main stages of its formation and determine how to attract investment as an integral part of innovation development.

The basic material of research. The Austrian scientist Josef Schumpeter (1883-1950) introduced the term and concept of «innovation» as a new economic category. J. Schumpeter, in the work «Theory of Economic Development» (1911), first considered the impact of innovation on development and gave a definition of the innovation process. Firstly, innovation is a new or improved product, service, technology, introduced in the market, in production and economic activities, consumption, public life. Secondly, it is a process of implementation of changes and introduction of innovations [10]. Both foreign and domestic authors give different options for defining the concept of «innovation» (table 1).

Summarizing the concepts considered, we're able to conclude that the term «innovation» is interpreted in most of two positions: innovation as a specific process aimed at achieving results, and innovation as a result. 


\section{Definition of the term «innovation»}

\begin{tabular}{|l|l|}
\hline \multicolumn{1}{|c|}{ Author/Source } & \multicolumn{1}{c|}{ Definition } \\
\hline $\begin{array}{l}\text { J. Schumpeter } \\
{[10]}\end{array}$ & $\begin{array}{l}\text { Innovations are the processes of the scientific and technical changes in } \\
\text { order to create and use new types of consumer goods, production and } \\
\text { vehicles, new markets and forms of industrial organization. In the process } \\
\text { of creating innovations, there are three stages: inventions, innovations, } \\
\text { diffusion. }\end{array}$ \\
\hline $\begin{array}{l}\text { Law of Ukraine } \\
\text { «On innovation } \\
\text { activity» [11] }\end{array}$ & $\begin{array}{l}\text { Innovations are newly created and (or) improved competitive } \\
\text { technologies, products or services, organizational and technical solutions } \\
\text { of production, administrative, commercial, or other nature, which } \\
\text { improve the structure and quality of production and (or) social sphere. }\end{array}$ \\
\hline P. Drucker [12] & $\begin{array}{l}\text { Innovations are the results, all the rest are costs. This is the main tool of } \\
\text { entrepreneurship, which gives resources the ability to create material } \\
\text { goods. In other words, anything that allows keeping more benefits that are } \\
\text { material from available resources. }\end{array}$ \\
\hline $\begin{array}{l}\text { D. Chervaneva, } \\
\text { L. Neikova [13] }\end{array}$ & $\begin{array}{l}\text { Innovation is the technical and economic process, which due to the } \\
\text { practical use of intellectual products - ideas and inventions, leads to the } \\
\text { creation of the best properties of new products and new technologies, } \\
\text { which, appearing on the market as innovations, can provide additional } \\
\text { income. }\end{array}$ \\
\hline $\begin{array}{l}\text { R. Fatkhutdinov } \\
\text { [14] }\end{array}$ & $\begin{array}{l}\text { Innovation is the result of the implementation of an innovation in order to } \\
\text { change the object of management and obtain economic, social, } \\
\text { environmental, scientific, technical, or another effect. }\end{array}$ \\
\hline
\end{tabular}

Source: Developed by the authors using [10-14]

Every manager should strive for constant innovation in his company. Thus, the goods and services produced become high quality and cheap, so, therefore, meet the needs of their customers. Enterprise innovation policy (EPP) is a part of the general policy of the enterprise, which determines the purpose, conditions, and process of innovation of the enterprise and establishes the order of interaction of scientific and technical, production, economic and marketing activities in the development and implementation of innovations. Promising the development of a modern enterprise requires the development and implementation of appropriate innovation policy, which should be based on strategic goals and solving tactical tasks for further development of the enterprise $[3 ; 4]$.

The theoretical foundations of innovation policy are adjusted depending on the type of activity of the enterprise. Therefore, when considering the innovative policy of the seaport, it is important to determine its special characteristics (purpose, objectives, functions, principles, etc.) (Fig. 1).

Innovation policy is based on two opposite subsystems. On the one hand, it is the needs of the market, consumers, marketing policy of the enterprise, and on the other - resources: achievements in science and production, technology, management mechanisms, organizational culture of the enterprise, material, labor, financial and information resources. 


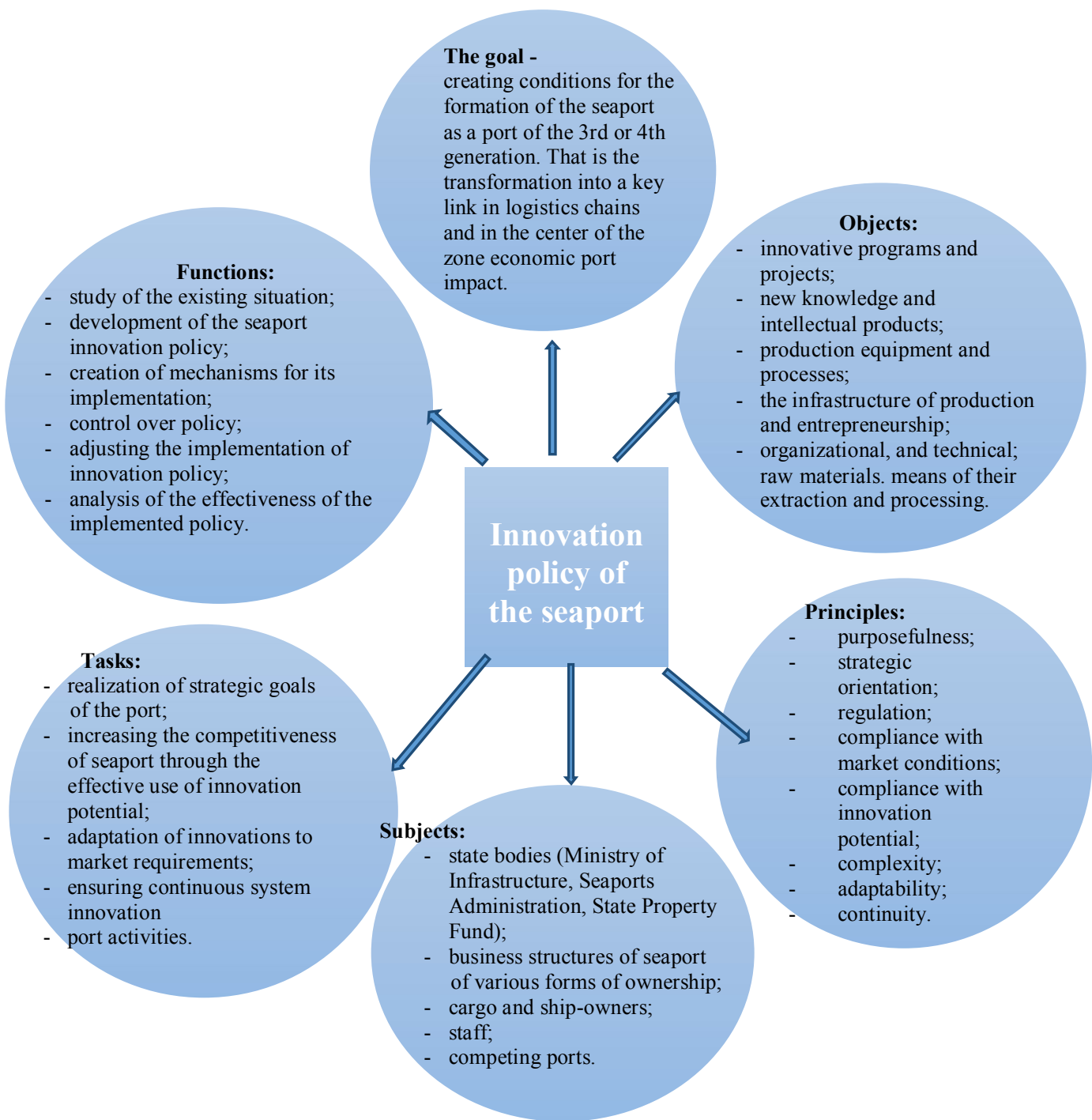

Fig. 1. Theoretical foundations

of the concept of «innovation policy of the seaport»

Source: Developed by the authors using [2-9; 15]

Having identified the main theoretical principles of innovation policy, it is important to identify components of the innovation policy of the enterprise, which equally apply to the seaport $[4 ; 6$; 15] (Fig. 2).

1. Marketing policy is not only an element of innovation policy but also a tool that regulates and determines inno- vation. On the one hand, marketing policy involves the development, management, and modernization of market and product strategies. On the other hand, marketing policy is a tool for innovation, because it determines the feasibility of innovations, their relationship with the market situation and the internal environment of the enterprise. 
РОЗВИТОК МЕТОДІВ

УПРАВЛІННЯ ТА ГОСПОДАРЮВАННЯ

НА ТРАНСПОРТІ, № 3 (72), 2020
2. Innovation is an intellectual product because by its origin it involves the implementation of new research or design solutions (R\&D). Accordingly, research and development are a source of innovation, and therefore an integral part of innovation policy.

3. The organizational structure of the enterprise must correspond to the ongoing innovation processes. Accordingly, the ability of the management system to function effectively should be ensured by the management structure of the organization. Therefore, it is important to create a unit that will be responsible for the implementation and monitoring of innovation processes. Personnel policy determines the general directions of work with employees of the enterprise, forms requirements to existing and potential specialists. The corporate policy of the enterprise determines the attitude of employees not only to the company and to each other, but also to innovation processes.

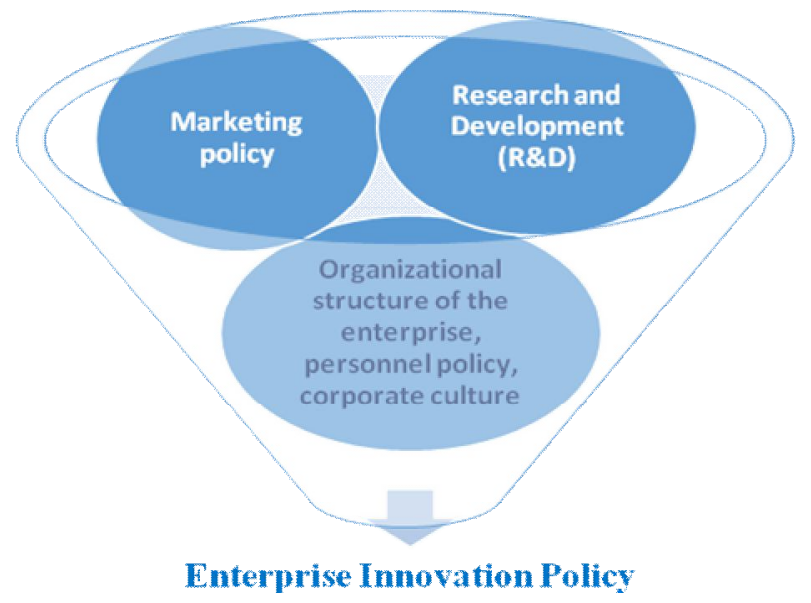

Fig. 2. Components of the innovation policy of the enterprise

Source: Developed by the authors using [4; 6; 15]

Having studied the essence of innovation and innovation policy, we can determine the stages of implementation of innovation policy in the enterprise (Fig. 3).

The first step to the development of innovation policy of the enterprise is to identify the relevance of the formation of the innovation policy for the organization and assess its innovation potential. The definition of this criterion is possible by applying a system of indicators that (table 2):

- have to include indicators that characterize the innovation potential for all components;

- have to provide an opportunity to compare the indicators used for analysis at different enterprises;

- have to focus on the implementation of current and future tasks of the enterprise;

- must be consistent with the existing reporting at the enterprise;

- have costs for collecting and processing information according to the selected system of indicators should be minimal. 
Identifying the

relevance of

innovation policy

for the enterprise
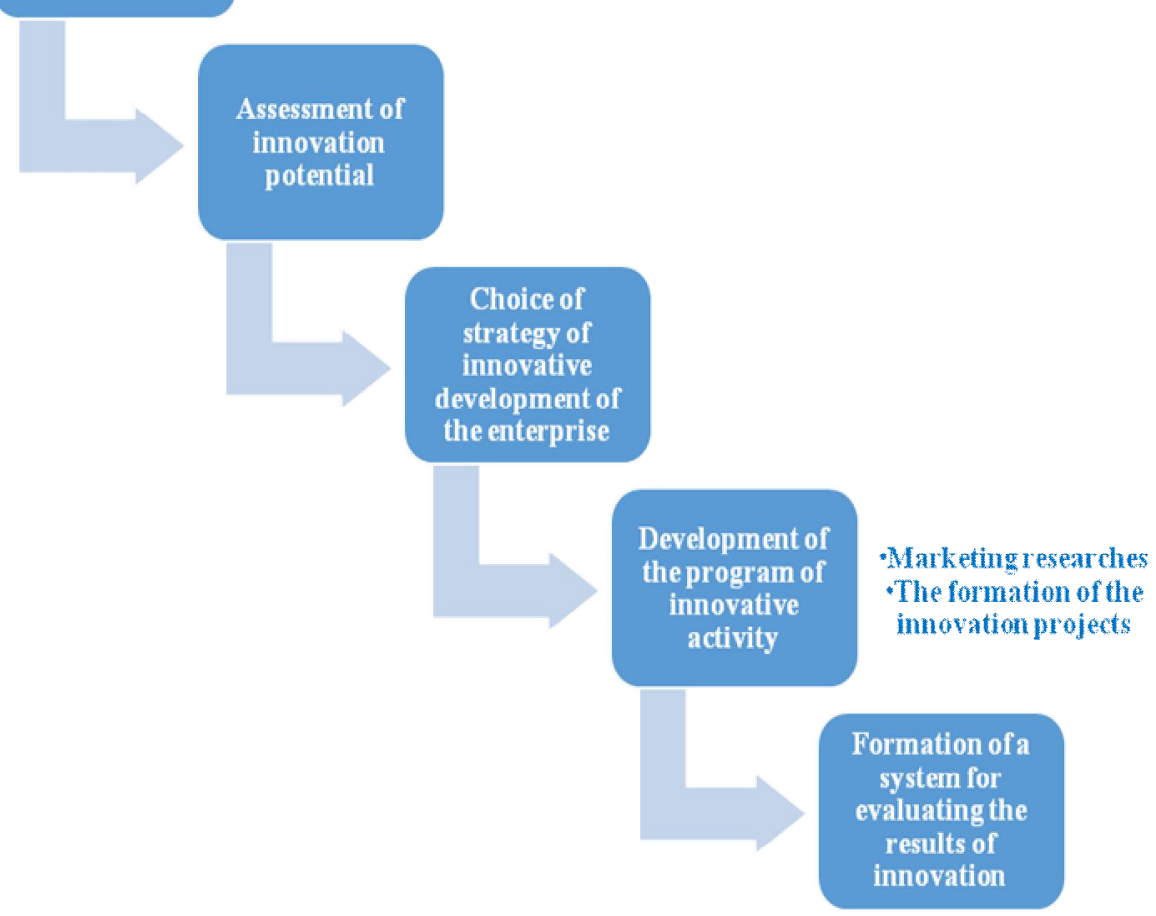

Fig. 3. The stages of implementation of innovation policy in the enterprise

Source: Developed by the authors using [5]

To ensure a systematic approach to planning and implementation of innovation activities at the enterprise, it is necessary to organize and compliance to a certain order of innovation policy. Therefore, the next step towards its implementation will be the choice of innovation strategy.

According to J. Gilbert, innovation strategy determines the extent to which and how a firm tries to use innovation, execute its business strategy and increase its productivity [1].
An apt definition of the innovation strategy as a purposeful activity to identify the most important areas, the choice of priorities for the development of the enterprise and the development of a set of measures necessary to achieve them.

This is a set of rules and regulations that determine the procedure for changing the system of selection and implementation of innovations, both in technology and in technology management [18]. 
DEVELOPMENT OF MANAGEMENT

AND ENTREPRENEURSHIP METHODS

ON TRANSPORT, № 3 (72), 2020
РОЗВИТОК МЕТОДІВ

УПРАВЛІННЯ ТА ГОСПОДАРЮВАННЯ

НА ТРАНСПОРТІ, № 3 (72), 2020

Table 2

The system of indicators for integrated assessment of innovative potential of enterprise

\begin{tabular}{|c|c|}
\hline $\begin{array}{l}\text { The component of the } \\
\text { enterprise' activity }\end{array}$ & Indicators \\
\hline Financial component & $\begin{array}{l}\text { - } \text { the share of internal expenses on research and development and } \\
\text { acquisition of technologies in the total costs of production; } \\
\text { - knowledge intensity of the products that are produced; } \\
\text { - } \quad \text { provision of the intellectual property; } \\
\text { - } \\
\text { the share of costs for the acquisition of intangible assets in total } \\
\text { costs for R\&D; } \\
\text { the share of costs for enhancement of human resource skills in } \\
\text { the total costs of R\&D; } \\
\text { - state sources of funding R\&D. }\end{array}$ \\
\hline Staff components & 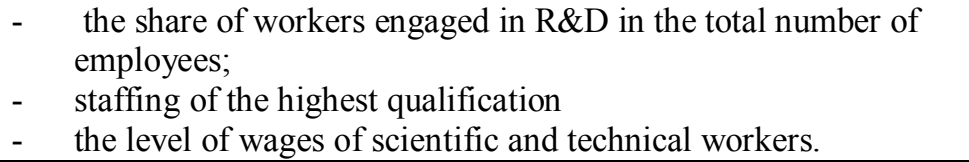 \\
\hline $\begin{array}{l}\text { Material and } \\
\text { technical component }\end{array}$ & $\begin{array}{ll}- & \text { technical and technological base intended for R\&D; } \\
- & \text { the progressiveness of equipment; } \\
- & \text { equipment modernization; } \\
- & \text { the rate of introduction of new equipment. }\end{array}$ \\
\hline $\begin{array}{l}\text { Information } \\
\text { component }\end{array}$ & $\begin{array}{ll}- & \text { costs of information activities; } \\
- & \text { personnel engaged in information activities. }\end{array}$ \\
\hline Market component & $\begin{array}{ll}- & \text { rate of development of new products; } \\
\text { - } & \text { the share of innovative products in general volume of industrial } \\
\text { production; } \\
\text { - } \quad \text { the profitability of innovative products. }\end{array}$ \\
\hline
\end{tabular}

Source: Developed by the authors using [6; 16; 17$]$

Innovative strategies are full of diversity. They are classified according to the following characteristics: according to the direction of innovative development of the organization (product, technological, market, marketing, management strategy); according to the type of competitive strategic innovation behavior (violent, expert, commutative and patient); according to the type of reaction to breakthrough strategic innovations (ignoring innovations, destruction of innovations, implementation of innovations and switching to a new way of doing business); according to the degree of openness of the innovation model of the organization (strategies of open and closed innovation model); by the level of novelty of the introduced innovation (active and passive); by the type of competitive market behavior according to $M$. Porter and R\&D strategy. An apt classification of innovation strategies by M. Matvienko based on the model of R. D'Aveni [19].

The choice of the necessary strategy is followed by its gradual implementation through the components of innovation policy (marketing policy, implementation of $R \& D$, changes in organizational structure, corporate culture and personnel policy). The implemen- 
РОЗВИТОК МЕТОДІВ

УПРАВЛІННЯ ТА ГОСПОДАРЮВАННЯ

НА ТРАНСПОРТІ, № 3 (72), 2020 tation of innovations is considered effective if the set goals are achieved and the quantitative economic indicators correspond to the planned ones. The main criteria for evaluating the results of innovation are relevance, significance and multifaceted nature. Types of effect from the implementation of innovations are given in table. 3 .

Economic efficiency after the implementing innovations is characterized by the amount of additional income, for this purpose, calculate the annual economic effect.

In the transition period of a market economy, the introduction of new technical and technological solutions, modern production processes capable of producing competitive goods, as well as a systematic assessment of the results of such implementation using the considered indicators is relevant.

Seaports of Ukraine are participants in the European and world economy and exist in the transition from the stage of post-industrialization to the stage of «new economy» («knowledge economy»), where the importance of innovation increases as a factor of economic growth. In order to create competitive advantages over foreign competitors, Ukrainian maritime enterprises need to develop and apply innovative technologies in their activities. Therefore, the urgency of implementing an innovation policy for Ukrainian seaports is more relevant than ever.

When assessing the innovative potential of the port, it is advisable to use a resource assessment approach [17].

Careful analysis should be carried out on human resources because it can be both a determining factor in the suc- cess of innovation and the main obstacle to innovative change.

When developing a strategy for innovative development of the seaport, it is important to take into account some features [9]:

- the need to coordinate the innovative activities of the port with similar activities of other maritime transport enterprises (shipping companies, shipyards, stevedoring companies, freight forwarding companies, etc.), due to their close relationships;

- the existence of a mechanism for effective management of innovation risks, necessary due to the fact that innovation in ports is a capital-intensive and time-consuming process;

- state control over the implementation of significant innovative changes due to the important socio-economic importance of sea trade ports in the national economy;

constant monitoring of domestic and world trends in scientific and technological progress and appropriate adaptation of the strategy and its components.

Significant capital investments are needed to reform the port economy. In order to implement the relevant innovation strategy, it is necessary to attract private investors, as ports, to a large extent, don't have the opportunity for self-investment.

The interest of the main exporters of products, state support, and stimulation of investors in minimizing risks and stabilizing tax legislation are important. Therefore, to increase investment attractiveness requires the cooperation of four main participants in the process: the legislature and the executive, business, and investment institutions [21]. 
DEVELOPMENT OF MANAGEMENT

AND ENTREPRENEURSHIP METHODS

ON TRANSPORT, № 3 (72), 2020
РОЗВИТОК МЕТОДІВ

УПРАВЛІННЯ ТА ГОСПОДАРЮВАННЯ

НА ТРАНСПОРТІ, № 3 (72), 2020

Types of effect after the implementation of innovation policy in the seaport

\begin{tabular}{|c|c|c|}
\hline $\begin{array}{c}\text { Types } \\
\text { of effect }\end{array}$ & The result & Indicators \\
\hline $\begin{array}{c}\text { Scientific } \\
\text { and } \\
\text { technical }\end{array}$ & $\begin{array}{l}\text { Shows changes in } \\
\text { technical \& operational } \\
\text { and consumer } \\
\text { characteristics of } \\
\text { innovations }\end{array}$ & $\begin{array}{l}\text { - increasing the scientific, technical and } \\
\text { organizational level of production; } \\
\text { - increasing in the number of copyright } \\
\text { certificates, patents, know-how, licenses, etc .; } \\
\text { - increasing the share of new information } \\
\text { technologies and technological processes; } \\
\text { - increasing the competitiveness of the enterprise } \\
\text { and its products. }\end{array}$ \\
\hline Economic & $\begin{array}{l}\text { Includes in value terms } \\
\text { all types of results and } \\
\text { costs due to the } \\
\text { implementation of } \\
\text { innovations }\end{array}$ & $\begin{array}{l}\text { - sales of innovative products; } \\
\text { - introduction of a new technological process; } \\
\text { - improving the use of production capacity; } \\
\text { - implementation of inventions, utility models, } \\
\text { industrial designs, innovation proposals, etc. }\end{array}$ \\
\hline Resource & $\begin{array}{l}\text { Reflects the impact of } \\
\text { innovation on the } \\
\text { volume of production } \\
\text { and consumption of a } \\
\text { particular type of } \\
\text { resource }\end{array}$ & $\begin{array}{l}\text { - increase in labor productivity (or it's } \\
\text { decreasing); } \\
\text { - increase in capital productivity of fixed assets } \\
\text { (or decrease in labour cost); } \\
\text { - accelerating the turnover of inventories, } \\
\text { receivables, cash, etc. }\end{array}$ \\
\hline Social & $\begin{array}{l}\text { Includes social results } \\
\text { of implementing } \\
\text { innovations }\end{array}$ & $\begin{array}{l}\text { - changes in the number of jobs at facilities } \\
\text { where innovations are implemented; } \\
\text { - improving the working conditions of workers; } \\
\text { - increase in income of the organization's staff; } \\
\text { - changes in the structure of production staff and } \\
\text { their qualifications, in particular changes in } \\
\text { the number of employees, including women } \\
\text { engaged in harmful types of work, changes in } \\
\text { the number of employees of different } \\
\text { qualifications, and those who need to improve } \\
\text { it. }\end{array}$ \\
\hline Ecological & $\begin{array}{l}\text { Includes the impact of } \\
\text { innovation on the } \\
\text { environment }\end{array}$ & $\begin{array}{l}\text { - reduction of pollution of the atmosphere, land, } \\
\text { water by harmful emissions; } \\
\text { - reduction of production waste; } \\
\text { - increasing the ergonomics of production } \\
\text { (reducing noise, vibration, electromagnetic } \\
\text { field, etc.). }\end{array}$ \\
\hline
\end{tabular}

Source: Developed by the authors using [6; 7; 20] 
DEVELOPMENT OF MANAGEMENT

AND ENTREPRENEURSHIP METHODS ON TRANSPORT, № 3 (72), 2020
РОЗВИТОК МЕТОДІВ

УПРАВЛІННЯ ТА ГОСПОДАРЮВАННЯ

НА ТРАНСПОРТІ, № 3 (72), 2020
The Ukrainian state is able to harmonize plans for the development of port infrastructure by developing effective mechanisms for cooperation with PJSC «Ukrainian Railways» and the State Agency of Roads of Ukraine [23]. Seaports are not subject to privatization, as they are included in the list of stateowned objects of strategic importance for the economy and security of the state (Resolution of the Cabinet of Ministers of 04.03.2015 № 83). Thus, the most effective way to stimulate the development of innovation in ports is the concessions (forms of public-private partnership PPP) [22]. For the state, the concession is always an instrument of economic growth and increase the level of market competition, attracting management resources, the latest equipment, technology, and modern organization of production processes while reducing budget costs. The investor is also interested in the concession given the possibility of risk sharing, guarantees of protection of the rights of the concessionaire, the imposition on the state of obligations to facilitate the implementation of projects. Thanks to such an effective source of investment, it will be possible to implement the following innovative tasks:

- to introduce SMART-infrastructure and technologies that promote automation and robotization of transshipment processes at sea terminals, and «green» technologies aimed at reducing harmful emissions from production processes in ports and obtaining energy from alternative sources;

- to ensure the implementation of innovative solutions for the creation of appropriate infrastructure for the possibility of receiving and servicing vessels that use liquefied gas as marine fuel;
- to renew the fixed assets of state stevedoring companies;

- to create specially designated places for temporary placement of freight transport with the provision of appropriate storage conditions for cargo that meet current environmental and sanitary standards [23].

Thus, domestic seaports need innovations to reach a new level and become 3rd and 4th generation ports.

Conclusions. Innovation policy is a part of the general policy of the enterprise, which determines the purpose, conditions, and process of innovation activity of the enterprise and establishes the order of interaction of scientific and technical, production, economic, and marketing activities in the process of development and implementation of innovations. When deciding on the implementation of innovation policy in the enterprise, it is important to choose the appropriate direction. Innovation policy consists of marketing policy, $\mathrm{R} \& \mathrm{D}$, the organizational structure of the enterprise, personnel policy, and corporate culture. The application of innovation policy should involve all its components, so being in interaction and based on the principle of synergy, the organization will be able to achieve the greatest effect from such interaction.

The implementation of innovation policy in the seaport should be carried out in stages: identifying the relevance of innovation policy for the port, assessing the innovation potential, choosing a strategy for innovative development of the enterprise, developing an innovation program, and forming an evaluation system.

All implemented innovations must be evaluated for efficiency. There are many types of effects from innovative measures, which are measured by rele- 
DEVELOPMENT OF MANAGEMENT

AND ENTREPRENEURSHIP METHODS ON TRANSPORT, № 3 (72), 2020
РОЗВИТОК МЕТОДІВ

УПРАВЛІННЯ ТА ГОСПОДАРЮВАННЯ

НА ТРАНСПОРТІ, № 3 (72), 2020 vant indicators. Nowadays, there is no simple uniform and suitable for all management conditions indicators of the effectiveness of innovation. We have considered only some of them. During the study of evaluation methods, it was found that for a comprehensive analysis it is necessary to evaluate enterprise' innovation policy not by one method, but by several at once. Thus, it is possible to cover a wider range of indicators and to examine in more detail the effectiveness of innovation policy.

Seaports of Ukraine are participants in the European and world eco- nomy. The set of competent management actions for the innovative policy of the seaport leads to its competitive advantage in the variable states of the external and internal environment, which, in turn, leads to its competitiveness.

The result of the implementation of innovation policy depends on taking into account the peculiarities of the state of the maritime port enterprise. The analysis of the study showed that the application of innovations in domestic seaports is necessary and should be accompanied by attracting a significant amount of investment.

\section{REFERENCES}

1. Illyashenko, S.M. (2010). Innovatsiynyy menedzhment [Innovation management]: [pidruchnyk]. Sumy: VTD - Universytet s'ka knyha [University book], 144 p. [In Ukrainian].

2. Kvasnyts'ka, R.S. \& Ardashkina, N.S. (2009). Osoblyvosti innovatsiynoyi diyal'nosti pidpryyemstv u suchasnykh umovakh [The features of the enterprise' innovation activity in modern conditions] // Visnyk Khmel'nyts'koho natsional'noho universytetu. Ekonomichni nauky - Bulletin of Khmelnytsky National University. Economic sciences, № 6, 247-251 [In Ukrainian].

3. Rymar, M.V. \& Lykun, N.V. (2012). Etapy ta pryntsypy zdiysnennya innovatsiynoyi diyal'nosti pidpryyemstva [Stages and principles of implementation of innovative activity of the enterprise]// Visnyk Natsional'noho universytetu «L'vivs'ka politekhnika». Problemy ekonomiky ta upravlinnya - Bulletin of the National University "Lviv Polytechnic». Problems of economics and management], № 725, 360-365. [In Ukrainian].

4. Maksimova, T.S., Filimonova, O.V. \& Lyshtvan, K.V. (2010). Formuvannya innovatsiynoyi polityky [Formation of innovation policy] // Ekonomichnyy visnyk Donbasu - Economic Bulletin of Donbass], № 2, 181-183 p. [In Ukrainian].

5. Chernenko, O. \& Nechytaylo, S. (2018). Formuvannya efektyvnoyi innovatsiynoyi polityky pidpryyemstva [Formation of effective innovation policy of the enterprise]. Efektyvna ekonomika - Effective economy, № 7. Retrieved from http://www.economy.nayka.com.ua/pdf/7_2018/55.pdf [In Ukrainian].

6. Alyabieva, O.M. (2019). Metodychnyy pidkhid do otsinky innovatsiynoho rozvytku mors'kykh portiv Ukrayiny [Methodical approach to the assessment of innovative development of seaports of Ukraine]. Ekonomika transportu $i$ zv"yazku. - Biznes-inform - Economics of Transport and Communications. Business inform, № 6, 163-168. Retrieved from file:///D:/Downloads/ metodichniy-p-dh-d-do-ots-nki-nnovats-ynogo-rozvitku-morskih-port-v.pdf [In Ukrainian]. 
7. Maltsev, M. (2017). Innovatsiynyy rozvytok mors'kykh portiv Ukrayiny [Innovative development of seaports of Ukraine]. Universytet $\cdot s$ 'ka nauka[University Science, 48-49 p. [In Ukrainian].

8. Postan, M., Kurudzhi, Yu. \& Moskvychenko, I. (2017). Metod poshuku rivnovazhnykh rishen' dlya duopoliyi lantsyuhiv postavok z urakhuvannyam innovatsiynoyi diyal'nosti pidpryyemstv [Method of finding equilibrium solutions for the duopoly of supply chains considering the innovative activity of enterprises]. Skhidnoyevropeys'kyy zhurnal korporatyvnykh tekhnolohiy - East European Journal of Corporate Technologies, № 3/4 (87), 25-30 [In Ukrainian].

9. Roshchina, N.V. (2009). Osoblyvosti rozrobky stratehiyi innovatsiynoho rozvytku mors'kykh torhovel'nykh portiv [Features of development of strategy of innovative development of sea trade ports]. [Bulletin of Transport Economics and Industry Visnyk ekonomiky transportu $i$ promyslovosti], № 26, 161-165 p. [In Ukrainian].

10. Schumpeter, J. (2007). Teoryya ékonomycheskoho razvytyya: per. s anhl [Theory of economic development: trans. with English]. Eksmo [M.: Éksmo], 386 p. [In Russian].

11. Zakon Ukrayiny` "Pro innovatsiynu diyal'nist'» vid 5 hrudnya 2012 \# 40-IV [Law of Ukraine "On innovation activity» № 406]. IV. Vidomosti Verxovnoyi Rady'Ukrayiny' (VVR). - 2002. \#36, St. 266. Retrieved from https:// zakon.rada.gov.ua/ laws/show/40-15 [In Ukrainian].

12. Drucker, P.F. (2012). Menedzhment. Vyzovy XXI veka: per. s anhl [Management. Challenges of the XXI century: trans. with English] Moskva: Mann, Yvanov y Ferber [Moscow: Mann, Ivanov and Ferber], 256 p. [In Russian].

13. Chervaneva, D.M. \& Neikova, L.I. (1999). Menedzhment innovatsiynoinvestytsiynoho rozvytku pidpryyemstv Ukrayiny [Management of innovation and investment development of enterprises of Ukraine]. K.: Vyd-vo "Znannya» [K.: Knowledge Publishing House], 516 p. [In Ukrainian].

14. Fatkhutdinov, R.A. (2011). Ynnovatsyonnyy menedzhment: Uchebnyk dlya vuzov 6-e vyd. [Innovation Management: A textbook for universities 6th ed.]. SPb.: Piter. [SPb.: Piter], 448 p. [In Russian].

15. Kolodyazh, I.V. (2020). Sutnist' innovatsiynoho potentsialu mors'koho torhovoho portu [The essence of the innovative potential of the sea trade port] Vseukrayins'ka naukovo-praktychna Internet-konferentsiya. "Stratehiya innovatsiynoho onovlennya ekonomiky Ukrayiny $v$ suchasnykh umovakh» [All-Ukrainian scientific-practical Internet conference - «Strategy of innovative renewal of Ukraine's economy in modern conditions»], 17-18 p. [In Ukrainian].

16. Loshchina, L.V. \& Milashenko, V.M. (2004). Kompleksna otsinka innovatsiynoho potentsialu pidpryyemstva: teoretyko-metodychni pidkhody [Complex assessment of the innovative potential of the enterprise: theoretical and methodological approaches]. Derzhavnyy VNZ «Ukrayins'ka akademiya bankivs'koyi spravy Natsional'noho banku Ukrayiny» [State University "Ukrainian Academy of Banking of the National Bank of Ukraine»], Sumy. Retrieved from http://dspace.uabs.edu.ua/bitstream/123456789/1234/1/comprehensive\%20ass essment\%20of\%20the\%20innovation.pdf. [In Ukrainian]. 
17. Gorshkov, R.K. (2004). Formyrovanye ynnovatsyonnoho potentsyala predpryyatyya: resursnyy podkhod [Formation of innovative potential of the enterprise: resource approach]. Problemy sovremennoy ékonomyky [Problems of modern economy], № 4, 9-14p. [In Russian].

18. Lanovska, G.I. (2014). Innovatsiyna stratehiya $v$ konteksti innovatsiynoyi polityky [Innovative strategy in the context of innovation policy]. Naukovyy visnyk Kherson. derzh. un-tet. Seriya «Ekonomichni nauky» [Scientific Bulletin of Kherson. state un-ty. Economic Sciences Series], Iss. 6, 42-50 p. [In Ukrainian].

19. Matvienko, M.V. (2014). Innovatsiyna stratehiya pidpryyemstv mors'koho transportu [Innovative strategy of sea transport enterprises]. Konferentsiya Sworld Naukovi doslidzhennya ta yikh praktychne zastosuvannya. "Suchasny stan i shlyakhy rozvytku» [Sworld Conference "Research and their practical application. Current state and ways of development»], Retrieved from http://www.sworld. education/index.php/ru/conference/the-content-ofconferences/archives-of-individual-conferences/oct-2014. [In Ukrainian].

20. Buzko, I.R., Vartanova, O.V. \& Golubchenko, H.O. (2002). Stratehichne upravlinnya innovatsiyamy ta innovatsiyna diyal'nist' pidpryyemstva: monohrafiya [Strategic management of innovations and innovative activity of the enterprise: monograph], Luhansk: [SNU Publishing House. V. Dalya], 176 p. [In Ukrainian].

21. Ilchenko, S. \& Oneshko, S. (2017). Finansovyy monitorynh pidpryyemstv portovoyi haluzi na osnovi oriyentovanoho na ryzyk pidkhodu [Financial monitoring of port industry enterprises based on risk-oriented approach]. Upravlinnya investytsiyamy ta finansovi innovatsiyi [Investment Management and Financial Innovations], Iss. 14, № 1 (cont.), 191-199p.

22. Shiryaeva, L.V., Afanasyeva, O.K. \& Kozhukhar, I.M. (2019). Doslidzhennya efektyvnosti reformuvannya portiv Ukrayiny na umovakh kontsesiyi [Research of efficiency of reforming of ports of Ukraine on the terms of concession] // Rozvytok metodiv upravlinnya ta hospodaryuvannya na transporti [Development of methods of management and administration on transport], № 4 (69), 58-73 p. [In Ukrainian].

23. Stratehiya rozvytku mors'kykh portiv Ukrayiny na period do 2038 roku [Strategy for the development of seaports in Ukraine for the period up to 2038] (2017). Derzhavne pidpryyemstvo «Administratsiya mors'kykh portiv Ukrayiny» [State Enterprise «Administration of Seaports of Ukraine»]. Retrieved from: https://mtu.gov.ua/files/\%D0\%A1\%D1\%82\%D1\%80\%D0\%B0\%D1\%82\%D0 \%....2038.pdf. 


\section{СПИСОК ЛІТЕРАТУРИ}

1. Ілляменко С.М. Інноваиійний менеджмент: [підручник]. Суми: ВТД Університетська книга, 2010. 144 c.

2. Квасницька Р.С., Ардашкіна Н.С. Особливості інноваційної діяльності підприємств у сучасних умовах // Вісник Хмельниџького наиіонального університету. Економічні науки. 2009. № 6. Т. 3. С. 247-251.

3. Римар М.В., Ликун Н.В. Етапи та принциии здійснення інноваційної діяльності підприємства // Вісник Національного університету «Львівська політехніка». Проблеми економіки та управління. 2012. № 725. C. 360-365.

4. Максимова Т.С., Філімонова О.В., Лиштван К.В. Формування інновачійноі політики // Економічний вісник Донбасу. 2010. № 2. С. 181-183.

5. Черненко О., Нечитайло С. Формування ефективної інноваційної політики підприємства // Ефективна економіка. 2018. № 7. URL: http:// www. economy.nayka.com.ua/pdf/7_2018/55.pdf

6. Аляб 'є'ва О.М. Методичний підхід до оиінки інноваційного розвитку морських портів України // Економіка транспорту і зв'язку. - Бізнесінформ. 2019. № 6. C. 163-168. URL: file:///D:/Downloads/metodichniy-p-dhd-do-ots-nki-nnovats-ynogo-rozvitku-morskih-port-v.pdf.

7. Мальиев М. Інноваційний розвиток морських портів Украйни // Університетська наука. 2017. С. 48-49.

8. Постан М., Куруджи Ю., Москвиченко I. Метод пошуку рівноважних рішень для дуополї ланцюгів поставок з урахуванням інноваційної діяльності підприємств // Східноєвропейський журнал корпоративних технологій. 2017. № 3/4 (87). С. 25-30.

9. Рощіна Н.В. Особливості розробки стратегії інноващійного розвитку морських торговельних портів // Вісник економіки транспорту $i$ промисловості. 2009. № 26. С. 161-165.

10. Шумпетер Й. Теория экономического развития: [пер. с англ.]. М.: Эксмо, 2007. $386 c$.

11. Закон Украйни «Про інноваиійну діяльність: за станом на 5 грудня 2012 р. // Верховна Рада України. Офіи. вид. Київ: Парлам. вид-во. 2012. $266 \mathrm{c.}$

12. Друкер П.Ф. Менеджмент. Вызовы ХХІ века: [пер. с англ.] // Москва: Манн, Иванов и Фербер. 2012. 256 с.

13. Черваньова Д.М., Нейкова Л.І. Менеджмент інноваційно-інвестииійного розвитку підприємств Украӥни. К.: Вид-во «Знання». 1999. 516 с.

14. Фатхутдинов Р.А. Инновационный менеджмент: [учебник для вузов]. 6-е изд. СПб.: Питер, 2011. 448 c.

15. Колодяж І.В. Сутність інноваційного потенціалу морського торгового порту // Всеукраїнська науково-практична Інтернет-конферениія. «Стратегія інновачійного оновлення економіки України в сучасних умовах». 2020. С. 17-18. 
16. Лощина Л.В., Мілашенко В.М. Комплексна оцінка інноваційного потениіалу підприємства: теоретико-методичні підходи // Державний ВНЗ «Украӥнська академія банківської справи Національного банку Украӥни», Суми. 2004. URL: http://dspace.uabs.edu.ua/bitstream/123456789/1234/1/ comprehensive\%20assessment\%20of\%20the\%20innovation.pdf.

17. Гориков Р.К. Формирование инноваџионного потенџиала предприятия: ресурсный подход // Проблемы современной экономики. 2004. № 4. С. 9-14.

18. Лановська Г.І. Інновачійна стратегія в контексті інновачійної // Науковий вісник Херсон. держ. ун-ту. Серія «Економічні науки». Вип. 6. 2014. C. 42-50.

19. Матвієнко М.В. Інновачійна стратегія підприємств морського трансnорту // Конференція Sworld «Наукові дослідження та їх практичне застосування. Сучасний стан і иляхи розвитку». 2014. URL: http:// www. sworld.education/index.php/ru/conference/the-content-of-conferences/archivesof-individual-conferences/oct-2014.

20. Бузько I.Р., Вартанова О.В., Голубченко Г.О. Стратегічне управління інновачіями та інноваційна діяльність підприємства: [монографія]. Луганськ: Вид-во СНУ ім. В. Даля. 2002. 176 с.

21. Ільченко C., Онешко С. Фінансовий моніторинг підприємств портової галузі на основі орієнтованого на ризик підходу // Управління інвестиціями та фінансові інновації. 2017. Buп. 14, № 1 (конт.). С. 191-199.

22. Ширяєва Л.В., Афанасьєва О.К., Кожухар I.М. Дослідження ефективності реформування портів України на умовах концесї // Розвиток методів управління та господарювання на транспорті. 2019. № 4(69). C. 58-73.

23. Стратегія розвитку морських портів України на період до 2038 року // Державне підприємство «Адміністрачія морських портів України». 2017. URL: https://mtu.gov.ua/files/\%D0\%A1\%D1\% 82\%D1\%80\% D0\%B0\% D1\% $82 \%$ D0\%....2038.pdf.

Article received 26.06.2020

Reference a JournalArtic: Afanasieva, Olga \& Pokora, Yana (2020). The formation of innovation policy of the seaport. 3 (72), 61-76. DOI 10.31375/2226-19152020-3-61-76. 